\title{
Composition of Venezurelan honeys from stingless bees (Apidae: Meliponinae) and Apis mellifera $\mathrm{L}$
}

\author{
P Vit ${ }^{1}$, S Bogdanov ${ }^{2, *}$, V Kilchenmann ${ }^{2}$ \\ 1 Dpto Ciencia de los Alimentos, Facultad de Farmacia, Universidad de Los Andes, \\ Mérida, Venezuela; \\ 2 Bee Department, Federal Dairy Research Station, 3097 Liebefeld, Bern, Switzerland
}

(Received 29 March 1993; accepted 11 August 1993)

\begin{abstract}
Summary - Forty stingless-bee and 21 Apis mellifera honeys from Venezuela were analysed for their essential composition. The stingless bees comprised 3 Melipona and 5 Trigona species. The moisture content of the honeys from the different stingless-bee species was significantly higher than that of the $A$ mellifera honeys. Generally, the stingless-bee honeys had a higher acidity than the $A$ mellifera honeys. The honeys from the Melipona species had lower diastase activity than the Trigona species. There were also differences in the acidity and the ash and nitrogen content of the honeys of the different stingless-bee species, but these differences might also be due to a different floral origin. While the $A$ mellifera honeys fulfilled the quality requirements set by the Codex Alimentarius, the honeys from the stingless bees failed to do so for several parameters, especially the quality factors such as water content, reducing sugars, acidity, and ash content.
\end{abstract}

Apis mellifera /stingless bees / Meliponinae / honey / physico-chemical analysis / Venezuela

\section{INTRODUCTION}

Apidae is the family to which honey bees and stingless bees belong; they have been assigned to separate subfamilies, the Apinae and the Meliponinae, respectively (Culliney, 1983). "The Meliponinae comprises 5 genera, the most extensive being Trigona and Melipona. The Trigona species occurs in every continent except Europe, whereas Melipona does not occur outside the Americas. Over 500 species of stingless bees are known, the majority are in South America and relatively few occur in Africa, Asia and Australia; they make honey as Apis species do and can be kept in hives as Apis mellifera and Apis cerana " (Crane, 1992). The classification of the Meliponinae subgenera adopted in the present work is that suggested by Camargo (Vit and Camargo, 1988).

\footnotetext{
${ }^{*}$ Correspondence and reprints.
} 
Stingless bee culture (meliponiculture) was formerly developed by the Maya civilisation, especially with Melipona beecheii, which is not found in Panama to the South (Weaver and Weaver, 1981; Crane, 1992). Unlike honey bees, stingless bees cannot sting and keep their honey in ellipsoidal pots made with cerumen (a mixture of wax and propolis) which vary in size with the species.

In Venezuela, there are many species of stingless bees but they and their products have scarcely been studied. The highest yields of Venezuelan stingless-bee honeys are given by $M$ favosa favosa, $M$ compressipes compressipes and $M$ trinitatis. However, honey is also harvested from the Trigona species (Vit and Camargo, 1988). Stingless-bee hunting is also a common practice in the central and eastern plains of the country. Our work can be seen as a specific contribution on stingless-bee honeys, while some more general work on VenezueIan meliponiculture have previously been published (Stejskal, 1962; Rivero, 1972, Bracho, 1993, Pulido, 1993).

The first report on the composition of stingless-bee honeys was given by Nogueira-Neto (1953) for one sample of $M$ quadrifasciata. Gonnet et al (1964) observed higher water content, invertase and acidity, lower $\mathrm{pH}$ and the lack of diastase for meliponin honeys when compared with $A$ mellifera honeys from Brazil. Roubik (1983) analysed the sugar content of honey stores from stingless bee from Panama. In 1991, Cortopassi-Laurino and Gelli compared Brazilian honeys from Africanized honey bees and from stingless bees; they found that moisture was the characteristic which best differentiated the 2 groups, while in colour both ranged between amber and light amber. Klink (1992) analysed water content, sugars, $\mathrm{pH}$, acidity and enzymes of stingless-bee honeys from Costa Rica. Besides the physico-chemical composition, the specific taste of stingless-bee honeys has also been mentioned (Schwarz, 1948; Nogueira-Neto, 1953; Wille, 1983).

Even if the therapeutic use of stinglessbee honeys is stated in the Maya Pharmacopea and their medicinal properties are still highly appreciated in numerous communities of Brazil, Colombia, Costa Rica, Guatemala, Mexico and Venezuela, there are no regulations for their quality control.

The aim of this study was to achieve a first physico-chemical characterisation from different species of Venezuelan stinglessbee honeys, to compare those with $A$ mellifera honeys from Venezuela. We also wanted to see to what extent these native honeys fulfilled the honey quality requirements suggested by the Codex Alimentarius Commission (1969) and by the VenezueIan regulations for honey (COVENIN 2136-84 and COVENIN 2191-84).

\section{MATERIALS AND METHODS}

\section{Samples}

Forty stingless bee honey samples, each sample varying from 50 to $2000 \mathrm{~g}$, were harvested from sealed honey pots in different locations of Venezuela in 1987-1988. Stingless-bee samples were also collected for the identification of the species. The $21 A$ mellifera honeys were of commercial origin.

The species of the Venezuelan stingless bees chosen for honey analysis here are listed in table 1 , as well as their common name and geographical origin. $M$ compressipes compressipes has a grey colour and is found in the west, while $M$ trinitatis has a brown colour and is found in the east; both of these species are called 'guanotas'.

Due to the restricted number of samples, which was not greater than 2 for some species, we can only refer separately to $M$ compressipes compressipes, $M$ trinitatis, $M$ favosa favosa and Frieseomelitta officinalis varia. The honeys of the other Trigona species were grouped together and were not considered for the statistical analysis 


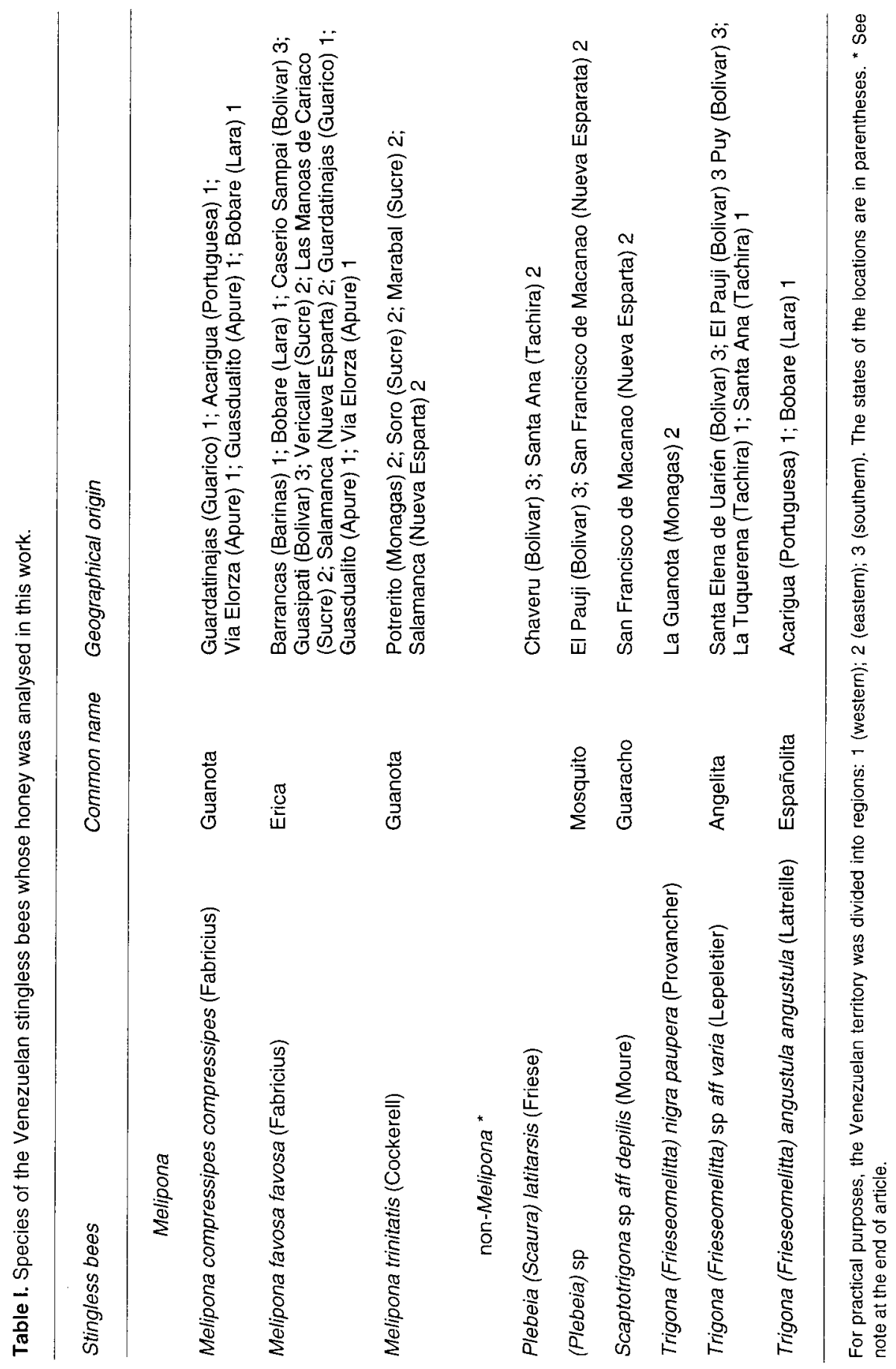


because of the high interspecifical variations. However, their results are included in the discussion.

\section{Analytical methods}

Water content, reducing sugars, sucrose, ash and the acidity were measured according to the Codex Alimentarius methods of analysis for honey (1969), which are basically the same as those suggested in the Venezuelan regulations for honey (COVENIN 2136-84). The diastase activity of the stingless-bee honeys was measured with the Phadebas test (Bogdanov, 1989), while that of the A mellifera honeys was determined by a qualitative iodine/starch method (Rodriguez and Martin, 1980). The nitrogen content was determined by the micro-Kjeldahl technique (AOAC, 1990).

A semiquantitative method based on the Fiehe reaction described by Rodriguez and Martin (1980) and the colour scale suggested by Vit (1988) was used to detect hydroxymethylfurfural (HMF) in the stingless-bee honeys. For that purpose, $2 \mathrm{ml}$ ether were added to $2 \mathrm{ml}$ of a $50 \%$ $(w / v)$ honey solution and thoroughly shaken. The ether extract was transferred into a test-tube and 3 drops of $1 \%(w / v)$ resorcinol in hydrochloric acid was added. The colour developed in $1 \mathrm{~min}$ was compared with that of HMF concentration of the standards. The readings 1,2 and 3 correspond to honeys with $\mathrm{HMF}<20,20-40$ and $>40$ $\mathrm{mg} \mathrm{HMF} / \mathrm{kg}$ honey.

The differences between the chemical parameters of the honeys of the different species were determined with Systat software using the Tukey test.

\section{RESULTS AND DISCUSSION}

Table II shows the physico-chemical composition of Venezuelan stingless-bee honeys and $A$ mellifera honey. In table III the statistical significance of the interspecies differences in the chemical parameters is given ( $P$ values) as determined by the Tukey test. The missing values and parameters mean that the $P$ values were higher than 0.05 .

\section{Water content}

The water content of the $A$ mellifera honeys was significantly lower than the honeys from the Melipona and the different Trigona species, except for $F$ officinalis varia. In the latter group it was observed that the moisture content varied with the geographical origin of the samples. The samples from the south (BOLIVAR) had an average water content of $16.16 \%$, while the samples from the west (TACHIRA) had an average of $24.87 \%$. This fact cannot be explained at present, since a more detailed sampling procedure in different tropical seasons is required. It is certainly interesting to discover stingless-bee honeys with even lower water content than A mellifera honeys, which was not previously reported. Even if we are not concerned with evolutionary subjects, we may suggest that in Venezuela $F$ officinalis varia shows a possible intraspecifical adaptation for honey moisture.

The high water content of stingless bee honeys compared with that of the $A$ mellifera honeys has already been mentioned by Schwarz (1948), Nogueira-Neto (1953), Gonnet et al (1964), Cortopassi-Laurino and Gelli (1991), Crane (1992) and Klink (1992). Crane (1992) pointed out that honeys from stingless bees are generally more acid and contain more water than A mellifera honeys, and that, for reasons that are not yet clear, they are fairly resistant to spoilage by unwanted fermentation. It is suggested that the resins present in the cerumen used to build up the storage pots could be present in honey and may serve as biocidal agents, preventing fermentation (Michener, 1974; Roubik, 1983). We suggest that specific moisture limits for stingless-bee honeys be set in the honey regulations. The Codex Alimentarius commission (1969) suggests a honey water content lower than $21 \%$, while according to the Venezuelan regulations (COVENIN 2191-84), the moisture content 


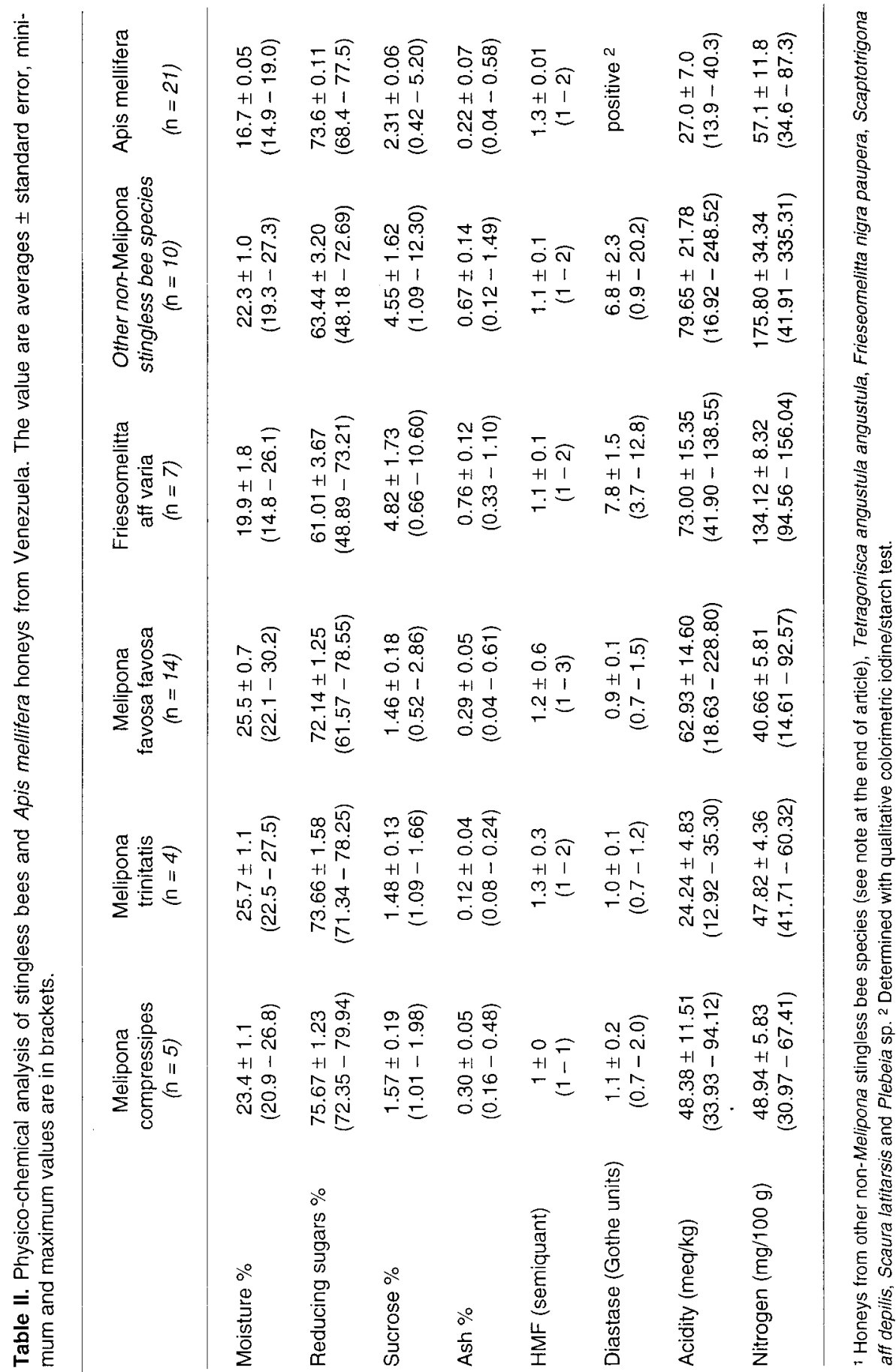


Table Ill. Differences between the honeys of the various bee species.

\begin{tabular}{llllllll}
\hline & AM/MC & AM/MT & AM/MF & AM/FO & MC/FO & MT/FO & MF/FO \\
\hline Moisture & 0.001 & 0.001 & 0.001 & 0.021 & & 0.048 & 0.001 \\
$\begin{array}{l}\text { Reducing sugars } \\
\text { Ash }\end{array}$ & & & 0.005 & & & & \\
Nitrogen & & & & 0.001 & 0.01 & 0.001 & 0.001 \\
& & & & 0.001 & 0.001 & 0.009 & 0.001 \\
\hline
\end{tabular}

The data shown in table II was subjected to the Tukey test. Only $P$ values smaller than 0.05 are given. Differences in other parameters between the different honeys proved to be insignificant. Abbreviations: AM: A mellifera; MC: $M$ compressipes compressipes; MT: $M$ trinitatis; MF: $M$ favosa; FO: $F$ aff varia.

should be lower than $20 \%$. The lower limit helps to decrease the fermentation danger in commercial honeys.

The stability to fermentation of the stingless-bee honeys could have something in common with the high antibacterial activity reported for Melipona honeys (Vit et al, 1992, Cortopassi-Laurino and Gelli,1992).

\section{Reducing sugars and sucrose}

The amount of reducing sugars in some Melipona honeys were similar to $A$ mellifera honeys, but a lower average was found for $F$ officinalis varia and for the different Trigona species. However, only the difference between the $F$ officinalis varia honeys and the $A$ mellifera honeys was significant. For all the stingless-bee honeys, the reducing sugar content varied from 48.18 to $79.94 \%$, which is wider and generally lower than the $68.4-77.5 \%$ found for $A$ mellifera honeys.

The sucrose content was somewhat lower in Trigona than in Melipona honeys and also showed a wider range of $1.09-12.30 \%$ when compared with $0.52-2.86 \%$ for Melipona and $0.42-5.20 \%$ for $A$ mellifera honeys, but the difference was not significant.
Honey is a natural product with known variable sugar composition in which more than 20 di- and trisaccharides have been identified besides the main fraction of monosaccharides, glucose and fructose (Doner, 1977). The sugar composition of honey depends on the sugars present in the botanical source, and also on their transformation by the enzymes secreted by bees.

Since here we are dealing with the general quality criteria for Venezuelan stingless-bee honeys, only the reducing sugars and the sucrose content is discussed. In another paper (Bogdanov and Vit, unpublished data) we consider the sugar spectrum of these samples.

\section{Ash}

The ash content of the Melipona honeys was significantly lower than that of the Trigona honeys, with ranges of $0.04-0.61$ for $M$ favosa favosa versus $0.33-1.10$ for $F$ aff varia. Moreover, $A$ mellifera honeys had a significantly lower content than the Trigona honeys. These differences could be attributed to the botanical origin, since the ash content depends strongly on the honey source. In another publication, the floral origin of the samples as determined by pollen 
analysis will be discussed (Vit and Ricciardelli d'Albore, manuscript in preparation). In the microscopic preparations of the samples used in the present study very few honeydew particles were encountered. The higher values observed for $F$ aff varia and for different Trigona species, could suggest some botanical preferences for specific sugar sources. During the field work, it was observed that some stingless bees collected fruit juices that did not attract honey bees. Fruit juices generally have a higher ash content than nectar. Feeding with fruit juices would thus raise the normal values for this parameter.

Since the botanical origin of honeys in Venezuela has not been studied, there is no differentiation for the ash content of honeys with different botanical origin in the national regulation for honeys (COVENIN 2191-84). It is required that honeys have an ash content lower than $0.5 \%$; commercial honeys from Venezuela with ash values higher than $0.5 \%$ are considered 'altered' (Vit, 1988). Boiled sugar cane syrup, which is sometimes sold as honey, has a higher ash content than $0.5 \%$. For this reason, the A mellifera honeys, with more than $0.5 \%$ ash are not included in this study. A higher maximal value for the ash content should be considered not only for stingless-bee honeys but also for $A$ mellifera ones.

\section{Hydroxymethylfurfural}

The HMF content was generally lower than $20 \mathrm{mg} / \mathrm{kg}$, with the exception of one sample of $M$ favosa favosa honey with a value higher than $40 \mathrm{mg} / \mathrm{kg}$.

HMF is known as a honey fraud indicator in developing countries, where it is a common practice to sell boiled sugar cane syrup as genuine honey. The Codex Alimentarius Commission (1969) specifies an HMF content for honey lower than $40 \mathrm{mg} / \mathrm{kg}$, but the Venezuelan regulations just specifies a 'neg- ative' result for the Fiehe reaction. For this reason a semiquantitative method was used in this work.

It would be interesting to study the evolution of HMF content in stingless-bee honeys kept in common market conditions, since the high water content and acidity values could increase the HMF content to a greater extent than the $A$ mellifera honeys.

\section{Diastase activity}

Our results showed that Melipona honeys had almost no diastase activity, while the Trigona honeys had normal, somewhat low diastase activities with average values of about 7 Gothe units. These activities lie within the range found in some $A$ mellifera monofloral honeys with low enzymatic activity (Persano-Oddo et al, 1990).

The diastase origin in honey is attributed to the salivary secretions of bees and not to the honey source, because this enzyme was found in honeys of sugar-fed bees (Stadelmeier and Bergner, 1986). Thus it can be concluded that Melipona species lack this enzyme. Gonnet et al (1964) also found no diastase activity but a normal invertase activity in Melipona honeys.

\section{Acidity}

There was no significant difference between the acidity values of stingless-bee honeys and that of $A$ mellifera honeys. However, in table II shows that $M$ trinitatis and $A$ mellifera had similar and lower acidity, while the acidity of $M$ compressipes compressipes, $M$ favosa favosa and Trigona honeys was generally higher.

As previously mentioned, stingless-bee honeys are organoleptically known as acid or sour honeys ( Schwarz, 1948; Nogueira- 
Neto, 1953; Gonnet et al, 1964; Rivero, 1972; Espina Perez and Ordetx, 1981; Wille, 1983; Crane, 1992). This characteristic is also reflected in the high acidity values of these honeys.

In Venezuela, honeys from 'guanotas' are generally known as being sweeter than honeys from 'ericas', and both of these Melipona honeys are widely relished. Honeys from Trigona are mainly used for medicinal purposes. As Cortopassi-Laurino and Gelli (1991) suggested, the high acidity of stingless-bee honeys should have an important implication by itself in the high antibacterial activity reported for this honeys when compared with $A$ mellifera.

The difference in acidity between $M$ compressipes compressipes and $M$ trinitatis could be a matter for a deeper study on the strategies used by these species of the same genus to keep their honey unspoiled at high moisture contents. If high acidity is not developed in honeys of $M$ trinitatis, other substances could be present for the prevention of fermentation.

\section{Nitrogen}

In tables II and III it can be observed that $F$ aff varia honeys had higher and significantly higher nitrogen content than the Melipona and the $A$ mellifera honeys, respectively, their values ranging from 94.6 to 156 , compared with 14.6-92.6 (Melipona) and 34.6-87.3 (A mellifera) mg N/100 g, respectively.

The nitrogen content is not included in the Venezuelan regulations for honey, but it was found as a useful honey fraud indicator since genuine honeys have higher nitrogen content than honey frauds (Vargas, 1983; Vit, 1987). The honey nitrogen is derived from the proteins and amino acids of honey. Generally, flower honeys have lower nitrogen content than honeydew honeys (White,
1962). The values found in the Trigona honeys are similar to those found in honeydew honeys.

\section{Botanical origin}

The results show that Trigona honeys had a more "honeydew-like" character (lower reducing sugar content, higher ash, acidity and nitrogen content) than the Melipona and honeys. However, the typical honeydew sugars melezitose and raffinose were not detected in the 'honeydew-like' samples (Bogdanov and Vit, unpublished data). Also, microscopic examinations of the samples revealed only very few honeydew particles in the honey samples, suspected to have a honeydew origin. As was mentioned earlier, it was observed that stingless bees are attracted by fruit juices, while $A$ mellifera are not. We think that the melissopalynological analysis (Vit and Ricciardelli d'Albore, unpublished data) could help to determine the botanical origin of stingless-bee honeys. Melissopalynological analysis of Venezuela A mellifera honeys was done by Ricciardelli D'Albore and Vit (1990). One general approach on the bee flora of Venezuela has been made by Lòpez-Palacios (1976).

\section{CONCLUSIONS}

Stingless-bee honeys have higher water content than A mellifera honeys. These differences are probably due to the differences between these bee subfamilies. Melipona and $A$ mellifera honeys had generally a lower reducing sugar content and a higher saccharose content than Trigona honeys, but these differences were not significant. The ash content was higher in Trigona honeys than in Melipona and $A$ mellifera honeys. The HMF content of all samples was lower than $20 \mathrm{mg} / \mathrm{kg}$. The diastase activity was lacking in Melipona honeys when com- 
pared with Trigona honeys, which had a diastase activity of about 7 Gothe units. Trigona honeys had higher acidity than Melipona honeys, while $M$ favosa favosa honeys had the highest acidity among Melipona honeys. Generally $A$ mellifera honeys had a lower acidity than stingless bee honeys with the exception of the $M$ trinitatis honeys. The nitrogen content of Trigona honeys was higher than in Melipona honeys and A mellifera honeys.

The observed differences in all parameters, except the water content, could be due to differences of the floral source or the bee species or to both of these factors. We are also aware that the analysed sample size was restricted and that the resulted 'significant differences' of the statistical analysis should not be overestimated. Further specific studies with more samples with stingless-bee honeys in Venezuela are necessary to determine the exact cause of these differences.

The quality factors, water content, reducing sugars, acidity and ash content of the stingless-bee honeys did not fulfil the Codex Alimentarius quality standards. For those, specific quality criteria should be established. For Venezuela, we would suggest to chose Melipona honeys only, because of their significant yields when compared with Trigona honeys, with, at least, the 2 already known denominations of 'guanotas' and 'ericas'.

\section{ACKNOWLEDGMENTS}

We gratefully acknowledge the support of this research by CONICIT (S1-1966) and CDCHT-ULA (FA-76-86). Some samples were kindly provided by Venezuelan beekeepers and meliponicultors. We are indebted to J Camargo from the University of Sao Paulo in Brazil, for the stingless bee identification; to $T$ Ivanov from the Experimental Station of Beekeeping of Sofia in Bulgaria, for his helpful comments on the manuscript; and to D Pulido from the Eastern University in Venezuela, for his valuable help to provide old stingless-bee references. We thank $D$ Vit for his help in the field work.

Résumé - Composition des miels vénézuéliens de méliponinés (Hymenoptera, Apidae) et d'Apis mellifera L. Quarante miels de méliponinés ( 3 espèces de Melipona et 6 espèces de Trigona) et 21 miels d'Apis mellifera ont été analysés (tableau I). Les résultats des analyses chimiques sont donnés dans le tableau II et les tests statistiques dans le tableau III. Le taux d'humidité des miels de méliponinés (moyennes de 19,9 à $25,7 \%, \min 14,8 \%, \max 30,2 \%$ ) est significativement plus élevé que celui des miels d'A mellifera (moyenne 16,7\%, $\min 14,9 \%$, max $19,0 \%$ ). Dans l'ensemble, les miels des méliponinés présentent une acidité plus élevée que ceux d'Apis mellifera. La teneur des miels de méliponinés en sucres réducteurs, en saccharose et en cendres est respectivement de 48,9 et $79,9 \%, 0,5$ à $12,3 \%$ et 0,04 à $1,49 \%$. Ils renferment 14,61 à $335,51 \mathrm{mg}$ d'azote par 100 $\mathrm{g}$ de miel et leur teneur en hydroxymethylfurfural (HMF) est inférieure à $20 \mathrm{mg} / \mathrm{kg}$. L'acidité varie de 12,92 à $248,52 \mathrm{meq} / \mathrm{kg}$ et l'activité diastasique de 0,7 à 20,2 unités Gothe. L'activité diastasique des miels de mélipones (moyennes de 0,9 à 1,1 unités de Gothe) est plus faible que celle des miels de trigones (moyennes de 6,8 à 7,8 unités de Gothe). On a trouvé en outre des différences dans l'acidité et la teneur en cendres et en azote entre les miels des différentes espèces de méliponinés. Mais ces variations pourraient être dues à des différences au sein de la flore. Alors que les miels d' $A$ mellifera ont satisfait aux critères de qualité définis par le Codex Alimentarius, les miels des méliponinés n'ont pas rempli les exigences pour certains paramètres tels que l'acidité et les teneurs en eau, en sucres réducteurs et en cendres.

\section{Apis mellifera / Meliponinae / miel / com- position chimique / Venezuela}


Zusammenfassung - Zusammensetzung
der venezolanischen Honige von sta-
chellosen Bienen (Hymenoptera, Apidae)
und Apis mellifera L. Vierzig Honige von stachellosen Bienen und 21 Honige von Apis mellifera aus Venezuela wurden auf ihre Zusammensetzung analysiert. Die untersuchten stachellosen Bienen umfasste 3 Melipona- und 5 Trigona Arten (Tabelle I). Die Resultate der chemischen Analysen der Proben sind in Tabelle II, diejenigen der statistischen Analyse in Tabelle III wiedergegeben. Der Wassergehalt der Honige der verschiedenen stachellosen Arten war signifikant höher (Durchschnittswerte 19,9 bis $25,7 \%$, Min 14,8\%, Max 30,2\%) als derjenige der Mellifera-Honige (Durchschnittsgehalt $16,7 \%$, Min 14,9\% Max 19,0\%). Im allgemeinen hatten die Honige der stachellosen Bienen einen höheren Säuregrad als die Apis mellifera-Honige. Die Melipona- und Trigona-Honige wiesen folgende chemische Zusammensetzung auf: reduzierende Zucker 48,89 bis $79,94 \%$, Saccharose 0,52 bis $12,30 \%$, Asche 0,04 bis 1,49\%, Säure 12,92 bis $248,52 \mathrm{mval} / \mathrm{kg}$, Diastaseaktivität 0,7 bis 20,2 Gothe-Einheiten, Stickstoff 14,61 bis $335,51 \mathrm{mg} / 100 \mathrm{~g}$ Honig, Hydroxymethylfurfural (HMF): weniger als $20 \mathrm{mg} / \mathrm{kg}$ Honig. In den Melipona-Honigen war die DiastaseAktivität tiefer (Durchschnittswerte 0,9 bis 1,1 Gothe Einheiten) als in den Trigona-Honigen (Durchschnittswerte 6,8 bis 7,8 Gothe Einheiten). Beim Säuregrad und beim Ascheund Stickstoffgehalt traten auch Unterschiede zwischen den Honigen der verschiedenen Arten der stachellosen Bienen auf, die aber auch durch unterschiedliche Flora bedingt sein könnten. Während die Honige von $A$ mellifera den Qualitätsanforderungen des Codex Alimentarius entsprachen, erfülten die Honige der stachellosen Bienen verschiedene Qualitätskriterien nicht, vor allem in Bezug auf Wassergehalt, reduzierende Zucker, Säuregrad und Aschegehalt.

\section{Apis mellifera / Meliponinae / Honig / che- mische Zusammensetzung / Venezuela}

\section{REFERENCES}

Association of Official Analytical Chemists (1990) Official Methods of Analysis. 15th ed AOAC, Arlington, USA

Bogdanov S (1984) Honigdiastase: Gegenüberstellung verschiedener Bestimmungsmethoden, Mitt Gebiete Lebensm Hyg 75, 214-320

Brachu ME (1993) Habitos en cuanto a recollecion de polen, néctar materiales de construccion y agua en abejas del genero Melipona (Hymenoptera, Apidae), Memorias I Concencion Nacional de Apicoltura, Merida, 1986 (in Spanish)

Codex Alimentarius Commission (1969) Recommended European Regional Standard for Honey. FAO/OMS, CAC/RS 12, Rome

Comisiòn Venezolana de Normas Industriales (1984) Miel de Abejas. Métodos de Ensayo. COVENIN 2136-84, CT $10 \mathrm{~S} / 14$, Caracas (in Spanish)

Comisiòn Venezolana de Normas Industriales (1984) Miel de Abejas. COVENIN 2191-84, CT 10 S/14, Caracas (in Spanish)

Cortopassi-Laurino M, Gelli DS (1991) Analyse pollinique, propriétés physico-chimiques et action antibactérienne des miels d'abeilles africanisées Apis mellifera et de Méliponinés du Brésil. Apidologie 22, 61-73

Crane $E$ (1992) The past and present status of beekeeping with stingless bees. Bee World 73, 29-42

Culliney TW (1983) Origin and evolutionary history of honeybees Apis. Bee World 64, 29-38

Doner LW (1977) The sugars of honey. A review. J Sci Food Agric 28, 443-455

Espina Perez D, Ordetx G (1981) Apicultura Tropical (Tropical Apiculture). Editorial Tecnologica de Costa Rica, Cartago, Costa Rica (in Spanish)

Gonnet M, Lavie P, Nogueira-Neto P (1964) Étude de quelques caractéristiques des miels récoltés par certains Méliponines brésiliens. CR Acad Sci Paris 258, 3107-3109

Klink M (1992) Onderzoek naar fysische en chemische aspecten van siukervoedingshoning en Costa Ricaanse angelloze bijenhoning (Physical and chemical aspects of honeys of sugar fed honeybees and from stingless bees from Costa Rica). PhD thesis. Rijksuniversiteit, Utrecht, The Netherlands (in Dutch)

Lopez-Palacios S (1976) Catalogo para una Flora Apicola Venezolana (Catalog for a Venezuelan Bee Flora). Consejo de Publicaciones. Universidad de Los Andes, Mérida, Venezuela (in Spanish)

Michener CD (1974) The Social Behaviour of the Bees. Harvard University Press, Cambridge, USA

Nogueira-Neto P (1953) A Criacao de Abelhas Indigenas sem Ferrao (Meliponinae). Editora Chacaras e Quintais, Sao Paulo, Brazil (in Portuguese)

Persano-Oddo L, Baldi E, Accorti M (1990) Diastatic activity in some unifloral honeys. Apidologie 21, 17-24 
Pulido D (1993) Actividad inhibitoria de mieles, propolis y germicidas domesticos, Memorias I Convencion Nacional de Apicoltura, Merida, Venezuela, 1986 (in Spanish)

Ricciardelli D'Albore GC, Vit P (1990) Apicoltura nel Venezuela e spettro pollinico dei mieli che vi si producono (Beekeeping in Venezuela and pollen spectra for honeys). Apicoltura 6, 71-104 (in Italian)

Rivero R (1972) Abejas Criollas sin Aguijòn (Creole stingless bees). Colecciòn Cientifica Monte Avila, Caracas (in Spanish)

Rodrìguez B, Martin E (1980) Anàlisis de Alimentos (Food Analysis). Central University, Caracas (in Spanish)

Roubik DW (1983) Nest and colony characteristics of stingless bees from Panama (Hymenoptera: Apidae). J Kansas Entomol Soc 56, 327-355

Schwarz H (1948) Stingless Bees (Meliponidae) of the Western Hemisphere. Bull Am Mus Natl Hist 90, 1 546

Stadelmeier M, Bergner KG (1986) Protein des Bienenhonigs. VII. Eigenschaften und Herkunft der Honigamylase. Z Lebensm Unters Forsch 182, 196 199

Stejskal M (1962) Duft als 'Sprache' der tropischen Bienen (Scent as language of tropical bees). Südwestdisch Imker 14, 271 (in German)

Vargas T (1983) Estudio fissico-quìmico de miel en el estado Aragua, su aplicaciòn en el control de fraudes (Physico-chemical study of honeys from the state of Aragua, its application to control frauds). Internal Report Central University of Venezuela, Maracay, Venezuela (in Spanish)

Vit $P$ (1987) Utilidad de la determinaciòn del contenido de nitrògeno en el control de calidad de mieles venezolanas (Use of nitrogen determination for honey quality control in Venezuela). Acta Cient Venez 39, 210 (in Spanish)

Vit $P$ (1988) Clasificaciòn de mieles comerciales venezolanas segùn sus caracteristicas fisico-quimicas y organolépticas (Physico-chemical and organoleptic classification for Venezuelan commercial honeys). Internal Report, University of the Andes, Mérida, Venezuela (in Spanish)

Vit P, Camargo J (1988) Estudio bromatológico de las mieles de abejas sin aguijòn producidas en Venezuela (Bromatological study of stingless bee honeys produced in Venezuela). Acta Cient Venez 39, 210 (in Spanish)

Vit P, Rios M, Novoa ML, Reinosa J, Camargo J (1992) Antibacterial activity and mineral content of Venezuelan stingless-bee honeys. Abstracts Fifth International Conference on Apiculture in Tropical Climates, Trinidad

Weaver N, Weaver EC (1981) Beekeeping with the stingless bee Melipona beecheii by the Yucatecan Maya. Bee World 62, 7-19

White, J (1962) Composition of American honeys, Tech Bull No 1261, US Department of Agriculture

Wille A (1983) Biology of stingless bees. Annu Rev Entomol $28,41-64$

\section{Note added in proof:}

In the literature, stingless bee systematics is apparently a controversial subject. Crane (1992) stated "The Meliponinae comprises 5 genera, the most extensive being Trigona and Melipona". But that same year, Camargo and Menezes Pedro published a mini-review on the systematics of Meliponinae, in Apidologie 23, 509-522, where discriminative characters were not simplified and considerably enlarged the subfamily genera number up to 21 . What we called Trigona spp in our work were simply non-Melipona spp stingless bees. This correction was made in tables I and II. 